\title{
Estimating Extent of Vulnerability of Agriculture and Livelihoods to Climate Change
}

\author{
K. V. Raju ${ }^{1}$, A. V. R. Kesava Rao ${ }^{2} \&$ R. S. Deshpande ${ }^{3}$ \\ ${ }^{1}$ Policy and Impact Group, Regional Program-Asia, International Crops Research Institute for the Semi-Arid Tropics, \\ Patancheru, Telangana, India \\ 2 ICRISAT Development Centre, International Crops Research Institute for the Semi-Arid Tropics, Patancheru, \\ Telangana, India. Email: k.rao@cgiar.org \\ ${ }^{3}$ ISEC, Bengaluru, India. E-mail: rs.kalbandi@gmail.com \\ Correspondence: K. V. Raju, Theme Leader, Policy and Impact Group, Regional Program-Asia, International Crops \\ Research Institute for the Semi-Arid Tropics, Patancheru, Telangana, India. Email: kv.raju@cgiar.org
}

Received: April 11, 2018

doi:10.5430/jms.v9n2p82
Accepted: May 9, 2018

Online Published: May 20, 2018

URL: https://doi.org/10.5430/jms.v9n2p82

\begin{abstract}
Vulnerability assessments can play a vital role in designing appropriate adaptation and mitigation policies targeted towards climate change and its impacts on ecosystems, and those who depend upon these resources for their livelihoods. This paper assesses climate change in Karnataka, the agriculture and livelihoods contexts of vulnerability. Karnataka state has the second largest area under rainfed agriculture in India and several studies have shown that climate change is happening in the state. Agriculture sector is vulnerable to climate variability and change across its three regions: coastal, hilly and plains.

Long-period monthly rainfall data (1901-2016) at district, region and state level was collected from India Meteorological Department and other sources and changes in seasonal and annual rainfall are analyzed. A Principal Component Analysis (PCA) was run on a dataset of seven variables for agricultural vulnerability and ten variables for livelihood vulnerability across thirty districts. The PCA generated three components for each index that broadly represented the underlying themes of agriculture and livelihood vulnerability present in the larger data set. Two vulnerability indices i.e., agricultural vulnerability index and livelihood vulnerability index were developed for all districts.

Long-period rainfall analysis showed a small decreasing trend in annual rainfall at the state level. South-eastern region is becoming slightly wetter, while parts of hilly region becoming drier. In one district, rainfall reduced by 460 $\mathrm{mm}$ and in the neighbour it raised by $250 \mathrm{~mm}$. Decadal meteorological drought analysis indicated an increasing trend in moderate droughts in north interior Karnataka. Indicators like cropping intensity, gross area irrigated and commercial crop area are the major drivers in determining the agricultural vulnerability. Livelihood index indicators like per capita income, population density, percentage of literacy rate and livestock units are major drivers for livelihood vulnerability. Agricultural vulnerability index analysis indicates four districts and livelihood vulnerability index analysis shows five districts as most vulnerable.
\end{abstract}

Keywords: climate change, vulnerability index, principal component analysis, agricultural vulnerability, livelihood vulnerability, Karnataka, India

\section{Introduction}

Vulnerability to natural hazards varies widely across communities, sectors and regions. Socio-economic vulnerability is determined by the internal structure of any social system that decides sensitivity of societies and communities to the incidence of hazards. Internal structure also helps to cope with damages from external shocks. It poses an important research question as to why there are different levels of vulnerability within a particular society, even in the context of similar hazards. Food and agriculture must be central to global efforts to adapt to climate change, through policies and actions that address vulnerabilities and risks and promote agricultural systems that are resilient and sustainable (FAO, 2016). This action must begin now - with the increasing intensity of climate change impacts, building resilience will become ever more difficult. 


\subsection{Climate Change}

Climate change is one of the major challenges in $21^{\text {st }}$ century faced by Agriculture in India, more so in the Semi-Arid Tropics (SAT) of the country. In recent years, natural and anthropogenic factors have impacted climate variability and contributed to a large extent to climate change. Global atmospheric concentration of $\mathrm{CO}_{2}$ has increased from pre-industrial level of 280 parts per million (ppm) to $400 \mathrm{ppm}$ in 2014 and reached to about $407.65 \mathrm{ppm}$ (Note 1) by May 2016. Global projections indicate higher temperature of 1.5 to $4.5^{\circ} \mathrm{C}$ by the year 2050 , as a result of enhanced greenhouse gases. Due to global warming, length of the crop-growing period (LGP) is likely to increase, however due to increase in day and night temperatures, physiological development is accelerated resulting in hastened maturation and reduced yields. Increased nighttime respiration may also reduce potential yields. With global climate change, rainfall variability is expected to further increase. When decrease in rainfall is coupled with higher atmospheric requirements due to elevated temperatures, the LGP is likely to shorten.

Changes in arid and semi-arid areas in India with associated shifts during 1971-2004 were reported (Kesava Rao et al., 2013), indicating a net reduction in the dry sub-humid area $(10.7 \mathrm{~m} \mathrm{ha}$ ) in the country, of which about 5.1 Million ha $(47 \%)$ shifted towards the drier side and about 5.6 Million ha (53\%) became wetter. They reported that the State of Madhya Pradesh has shown the largest increase in semi-arid area (about 3.82 Million ha) followed by Bihar (2.66 Million ha) and Uttar Pradesh (1.57 Million ha). Dryness and wetness are increasing in different parts of the country in the place of moderate climates existing earlier in these regions.

\subsection{Vulnerability}

A growing body of literature over the past two decades has identified climate change as the prime issue to global environmental degradation, and has analyzed the associated vulnerability and biodiversity loss (IPCC, 2007). According to Fussel (2007), climate related vulnerability assessments are based on the characteristics of vulnerable system spanning over physical, economic and social factors. The Intergovernmental Panel on Climate Change (IPCC), in its Second Assessment Report (IPCC, 1996), defines vulnerability as "the extent to which climate change may damage or harm a system." In addition, social scientists tend to view vulnerability as representing the set of socio-economic factors that determine people's ability to cope with stress or change (Allen, 2003) while climate scientists often view vulnerability in terms of the likelihood of occurrence and impacts of weather and climate related events (Nicholls et al., 1999).

IPCC defines vulnerability in terms of systems as "the degree to which a system is susceptible to, or unable to cope with, adverse effects of climate change, including climate variability and extremes" (IPCC, 2007). Vulnerability is a function of the character, magnitude and rate of climate variation to which a system is exposed, its sensitivity and its adaptive capacity (IPCC, 2007).

It is well understood that poor people in the poorest countries are the most vulnerable to the impacts of anthropogenic climate change (Stern et al., 2006). Any increases in climate extremes will exacerbate the vulnerability of all food-insecure people, including smallholders (Porter et al., 2014). Vulnerability assessments can play a vital role in the design of appropriate adaptation and mitigation policies targeted towards climate change and its impacts on ecosystems, and those who depend upon these resources for their livelihoods and well-being. Enhancement of adaptive capacity is necessary for reducing vulnerability to climate changes encountered in the frequency and intensity of extreme events, like floods and droughts which have deep impact on agriculture and livelihood (Sehgal et al., 2013).

People who live in arid or semi-arid regions, in low-lying coastal areas, in water limited or flood-prone areas, or on small islands are particularly vulnerable to climate change (Watson et al., 1996). It is clear that climate change will, in many parts of the world, adversely affect socio-economic sectors, including water resources, agriculture, forestry, fisheries and human settlements, ecological systems and human health with developing countries being the most vulnerable. On the other hand, developing countries have lesser capacity to adapt and more vulnerable (IPCC, 2001). There is an increasing need to develop indicators of vulnerability and of adaptive capacity both to determine the robustness of response strategies over time and to understand better the underlying processes (Adger et al., 2004). Vulnerability of socio-economic and agriculture sectors in Karnataka was earlier attempted (Raju et al., 2016). In Karnataka, agricultural farmers and agricultural labourers form $56 \%$ of the total workforce (Government of Karnataka, 2005) and this is considered as one of the driving forces in determining the socio-economic vulnerabilities of communities in Karnataka. 


\section{Objectives, Data and Methods}

The key objectives of this assessment are: (a) to assess the climate change in Karnataka, (b) to assess vulnerability of agricultural sector across the districts of Karnataka; and (c) to estimate the livelihood vulnerability of the districts of Karnataka.

Data pertaining to climate, various agricultural and livelihood indicators were collected and compiled from different sources such as India Meteorological Department (IMD, 2013), Census of India (2011) and Statistical Abstracts of Karnataka (Directorate of Economics and Statistics), 2008-09, 2009-10 and 2010-11. Monthly rainfall data for the period 1956 to 2015 was used to assess the district-wise changes in seasonal and annual rainfall. To understand the agricultural and livelihoods profile, the study analyses important indicators across the districts of Karnataka. This has been done by consultation with experts and based on previous studies (Table 1).

Table 1. Indicators used in earlier vulnerability studies

\begin{tabular}{|c|c|c|}
\hline Study / Author (s) & Major indicators used & Indicators used in the present study \\
\hline $\begin{array}{l}\text { Vulnerability to agricultural } \\
\text { drought in Western Orissa: A } \\
\text { case study of representative } \\
\text { blocks (Swain and Swain, } \\
\text { 2011) }\end{array}$ & $\begin{array}{l}\text { Livelihood indicators used: irrigation, crops, marginal } \\
\text { farmers, land use pattern, literacy rate, population } \\
\text { density, institutional factors, forest area, total } \\
\text { geographic area, barren and other fallow land. }\end{array}$ & $\begin{array}{l}\text { Irrigation, marginal farmers, literacy } \\
\text { rate, population density, } \\
\text { fallow land }\end{array}$ \\
\hline $\begin{array}{l}\text { Analysis of vulnerability } \\
\text { indices in rarious } \\
\text { agro-climatic zones of Gujarat } \\
\text { (Hiremath and Shiyani, 2013) }\end{array}$ & $\begin{array}{l}\text { Density of population, literacy rate, cropping intensity, } \\
\text { irrigation, forest area, food crop, non-food crop, net } \\
\text { sown areas, livestock population, main workers, } \\
\text { cultivators, marginal workers, non-workers. }\end{array}$ & $\begin{array}{l}\text { Density of population, literacy rate, } \\
\text { cropping intensity, irrigation, net } \\
\text { sown areas, livestock population, } \\
\text { non-workers }\end{array}$ \\
\hline $\begin{array}{l}\text { A simple human vulnerability } \\
\text { index to climate change } \\
\text { hazards for Pakistan (Khan } \\
\text { and Salman, 2012). }\end{array}$ & $\begin{array}{l}\text { Density of population, literacy, sanitation, electricity, } \\
\text { livestock }\end{array}$ & $\begin{array}{l}\text { Density of population, literacy, } \\
\text { livestock population }\end{array}$ \\
\hline $\begin{array}{l}\text { Environmental benefits and } \\
\text { vulnerability reduction } \\
\text { through Mahatma Gandhi } \\
\text { National Rural Employment } \\
\text { Guarantee Scheme (IISc, } \\
\text { 2013) }\end{array}$ & $\begin{array}{l}\text { Groundwater depth, cropping intensity, irrigation } \\
\text { intensity, net area irrigated, number of days of } \\
\text { irrigation water availability, area under food grain } \\
\text { production, crop yields, livestock population, soil } \\
\text { organic carbon and soil erosion, migration, wage rates, } \\
\text { percentage change in the number of days of } \\
\text { employment, livestock population. }\end{array}$ & $\begin{array}{l}\text { Cropping intensity, } \\
\text { livestock population }\end{array}$ \\
\hline $\begin{array}{l}\text { Climate change impact on } \\
\text { livelihood, vulnerability and } \\
\text { coping mechanisms: A case } \\
\text { study of West Arid Zone, } \\
\text { Ethiopia (Senbeta, 2009). }\end{array}$ & $\begin{array}{l}\text { Land size, livestock number, literacy, sex, gender and } \\
\text { age }\end{array}$ & Livestock number, literacy \\
\hline $\begin{array}{l}\text { Quantitative assessment of } \\
\text { vulnerability to climate } \\
\text { change (ICRISAT, 2009) }\end{array}$ & $\begin{array}{l}\text { Cropping intensity, irrigation area, total food grains } \\
\text { (tons) net sown area, literacy rate, density of } \\
\text { population, livestock, population, total food crops area, } \\
\text { total no food crops area, life expectancy }\end{array}$ & $\begin{array}{l}\text { Cropping intensity, irrigation area, } \\
\text { net sown area, literacy rate, density } \\
\text { of population, livestock population }\end{array}$ \\
\hline
\end{tabular}

Vulnerability to climate change is a comprehensive process affected by a large number of indicators. However, it is not possible to consider all the available indicators, so only the most significant and representative indicators relevant to Karnataka state were selected in the development of vulnerability indices. Indicators considered in this study are:

Agricultural indicators: Net sown area (3 years average), cropping intensity, area under commercial crops to the total cropped area (TCA), percentage irrigated area to TCA (3 years average), number of tractors/1000 hectare area sown, total fallow land (3 years average) and agricultural credit cooperative societies/lakh population.

$>$ Livelihood indicators: Population density, percentage population of Scheduled Caste (SC) and Scheduled Tribe (ST), literacy rate, percentage of marginal landholder $(<1$ hectare), percentage of non-workers, livestock units per 
lakh population, per capita income ( 3 years average), cropping intensity and percentage irrigated area to TCA ( 3 years average).

District-wise changes in agricultural and livelihood indicators were shown in graphs; district Abbreviations (Note 2) were used for district names in these graphs.

\subsection{Climate Change in Karnataka}

Karnataka state has three principal geographical zones: (1) the coastal region; (2) the hilly region known as Malnad; and (3) the Bayaluseeme region comprising the plains of Deccan plateau. Meteorologically the state is divided into coastal Karnataka, north interior Karnataka and south interior Karnataka. According to the Government of Karnataka, the state comprises of ten agroclimatic zones (Note 3) based on rainfall amount and distribution, soil type, texture, depth and physio-chemical properties, elevation, topography, major crops and type of vegetation.

In Karnataka, the southwest monsoon rainfall is likely to be more uncertain with both increasing and decreasing trends in different parts of the state.Increase in temperature and decline in rainfall were noticed over different regions of the state. During the period 1950-1990, average rise in annual temperature was $1.3^{\circ} \mathrm{C}$ in Karnataka (Rajegowda, 1992). Venkatesh et al. (2008) observed increased temperatures in November and December, which indicated availability of higher thermal energy for better vegetative growth during November while there was greater thermal stress during flowering period in December for post-rainy season sorghum crop.

Mean annual rainfall of Karnataka for the period from 1901 to 2000 indicated a definite declining trend (Panduranga et al., 2006). Time series of the annual rainfall of Karnataka show a cycle of sixteen years in which the first half of the cycle received less than the normal rainfall for the period from 1950 to 1958 and the second half of the cycle received more than normal for the period from 1959 to 1964. Devappa and Khageshan (2011) reported a decreasing trend in the annual rainfall at $3.44 \mathrm{~mm}$ per year for Kalaburagi district in Karnataka, based on data for 1961-2008. Rajegowda et al. (2000) have shown that there is a predominant shift in the initiation and termination of rainfall in the Eastern Dry agroclimatic zone to supply adequate moisture for crop growing period. This shift has been observed after 1990 and their mean monthly values also have changed. Singh et al. (2014) reported that during the period of 1971-2005, Coastal Karnataka districts showed decreasing precipitation trend with an average rainfall of $>25 \mathrm{~mm}$ per day.

Climate change analysis of Karnataka using gridded climate data of 113 years (1901-2013) indicated that areas under semi-arid and perhumid climates have increased by about 3,34,000 and 3,16,000 ha respectively (Kesava Rao et al., 2016) in the period 1991-2013 compared to the period 1901-90. Dry subhumid area increased by about $1,20,000$ ha while humid area reduced by about 1,61,000 ha.

While assessing climate change, it is an accepted method to find deviations from a base period. As per the WMO guidelines, 30-year continuous data is required to compute climatic normals. As district-wise rainfall of Karnataka is available up to the year 2015, in the present study, the immediate past 30-year period 1986-2015 is considered as the period 2 and the 30-year period 1956-1985 was considered as base period or period 1.

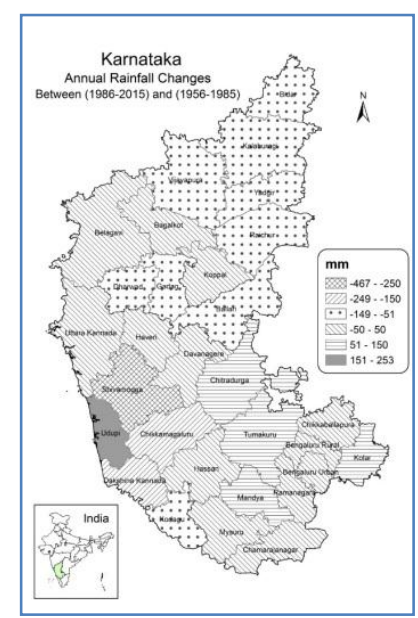

Figure 1. Annual rainfall changes in Karnataka 
Average monthly rainfall for all the 30 districts for both the periods 1 and 2 was computed and the differences worked out and Table 2 shows changes in seasonal rainfall. Annual rainfall changes are shown in Figure 1.

Table 2. Rainfall changes in Karnataka in two selected periods (1956-85 and 1986-2015)

\begin{tabular}{|c|c|c|c|}
\hline \multirow[b]{2}{*}{ District } & \multicolumn{3}{|c|}{ Rainfall change (mm) } \\
\hline & $\begin{array}{l}\text { SW Monsoon } \\
\text { (Jun-Sep) }\end{array}$ & $\begin{array}{l}\text { Post-Monsoon } \\
\text { (Oct-Dec) }\end{array}$ & Annual \\
\hline Udupi & 194 & 86 & 253 \\
\hline Chitradurga & 58 & 27 & 101 \\
\hline Mandya & 46 & 33 & 81 \\
\hline Kolar & 48 & 14 & 77 \\
\hline Tumakuru & 49 & 13 & 77 \\
\hline Hassan & 6 & 30 & 47 \\
\hline Davanagere & 22 & 19 & 41 \\
\hline Chamarajanagara & 30 & 14 & 25 \\
\hline Bengaluru Urban & 14 & -10 & 21 \\
\hline Mysuru & 8 & 29 & 21 \\
\hline Koppal & -21 & 13 & 14 \\
\hline Bengaluru Rural & 2 & 1 & 13 \\
\hline Chikkaballapura & 5 & -9 & -6 \\
\hline Ramanagara & 4 & 4 & -10 \\
\hline Belagavi & 11 & -5 & -26 \\
\hline Bagalkote & -26 & -4 & -33 \\
\hline Uttara Kannada & 13 & -8 & -34 \\
\hline Haveri & -36 & 1 & -49 \\
\hline Ballari & -40 & -5 & -52 \\
\hline Bidar & -63 & -3 & -57 \\
\hline Dharwad & -38 & -7 & -63 \\
\hline Raichur & -66 & -11 & -70 \\
\hline Kodagu & -37 & 3 & -75 \\
\hline Gadag & -48 & -14 & -76 \\
\hline Kalaburagi & -85 & -15 & -93 \\
\hline Vijayapura & -74 & -21 & -99 \\
\hline Yadgir & -168 & -21 & -181 \\
\hline Chikkamagaluru & -225 & 18 & -223 \\
\hline $\begin{array}{l}\text { Dakshina } \\
\text { Kannada }\end{array}$ & -298 & 74 & -227 \\
\hline Shivamogga & -473 & 12 & -467 \\
\hline State & -1188 & 258 & -1070 \\
\hline
\end{tabular}

\subsection{Droughts in Karnataka}

Drought is a climatic anomaly, characterized by deficient supply of moisture resulting either from sub-normal rainfall, erratic rainfall distribution, higher water need or a combination of all the three factors. As per the India 
Meteorological Department (IMD), meteorological drought over an area is defined as a situation when the monthly / seasonal rainfall received over the area is less than $75 \%$ of its long term average value. It is further classified as "moderate drought" if the rainfall deficit is between 26-50\% and "severe drought" when the deficit exceeds 50\% of the normal.

Monthly rainfall data of the three IMD Sub-divisions in Karnataka was collected from the Indian Institute of Tropical Meteorology, Pune for the period 1961-2016 (56 years) and occurrence of meteorological droughts in Kharif season (Jun-Oct) by taking month as a unit was assessed. Results show that drought occurrence is increasing in the North Interior Karnataka (Figure 2).

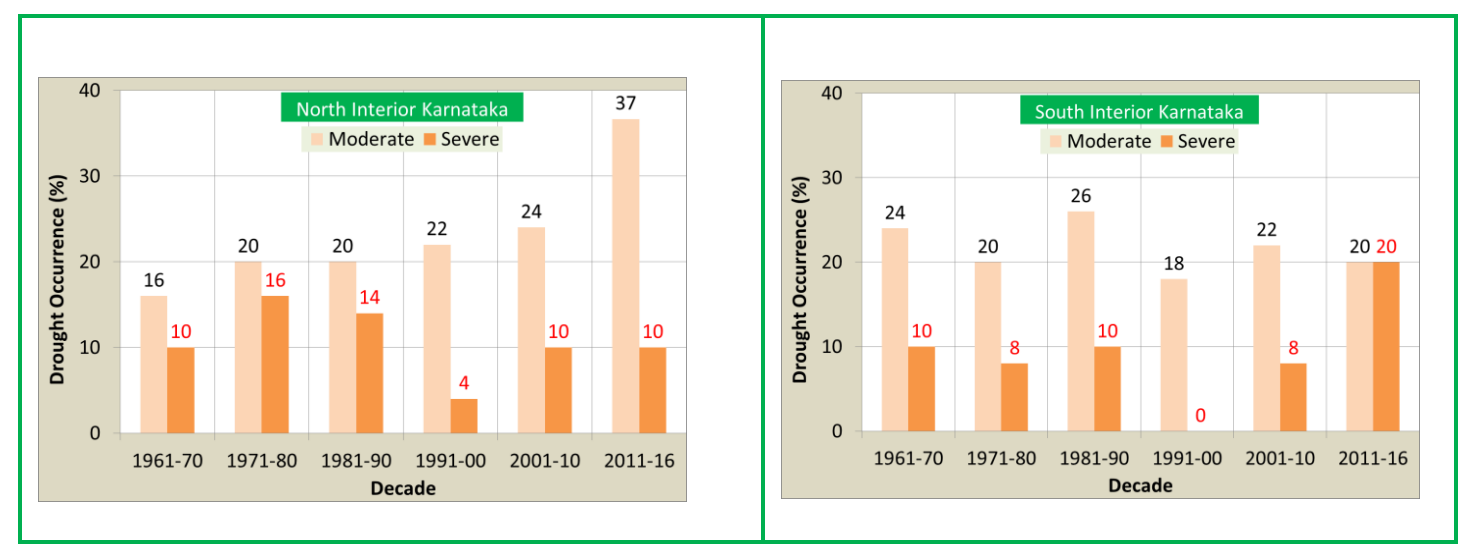

Figure 2. Decadal changes in meteorological droughts during Kharif season in Karnataka

Droughts of "Moderate" category are increasing in North Interior Karnataka, while "Severe" category droughts are increasing in South Interior Karnataka. No trends were seen for the Coastal Karnataka regions. Dry spells leading to drought in the flowering and grain-filling stages will affect crop yields adversely.

Table 3. Districts with indicators grouped into high and low incidence

\begin{tabular}{llll}
\hline No & Indicators & $\begin{array}{l}\text { High incidence } \\
\text { (from median value) }\end{array}$ & $\begin{array}{l}\text { Low incidence } \\
\text { (from median value) }\end{array}$ \\
\hline & Agriculture & 14 & 15 \\
\hline 1 & Net sown area (3 years average) & 14 & 15 \\
\hline 2 & Cropping intensity & 14 & 15 \\
\hline 3 & $\%$ area under commercial crops to TCA & 14 & 15 \\
\hline 4 & $\%$ irrigated area to TCA (3 years average) & 15 & 14 \\
\hline 5 & No. of tractors/1000 ha area sown & 15 \\
\hline 6 & $\begin{array}{l}\text { \% of total fallow land to total geographical area }(3 \\
\text { years average) }\end{array}$ & 14 & 15 \\
\hline 7 & $\begin{array}{l}\text { No. of agricultural cooperative credit societies/ lakh } \\
\text { population }\end{array}$ & 14 & 14 \\
\hline Socio-economic and livelihood & 15 & 15 \\
\hline 1 & Population density & 15 & 15 \\
\hline 2 & $\%$ SC and ST population & 15 & 15 \\
\hline 3 & $\%$ Literacy rate & 15 & 15 \\
\hline 4 & $\%$ of marginal land holder $(<1$ ha) & 15 & \\
\hline 5 & \% of non-workers & & 15 \\
\hline
\end{tabular}




\begin{tabular}{llll}
\hline 6 & $\begin{array}{l}\text { Livestock units per lakh population } \\
\text { (Livestock Unit }=1 \text { cattle }=1 \text { buffalo }=5 \text { sheep = 5 } \\
\text { goats) }\end{array}$ & 15 & 15 \\
\hline 7 & $\begin{array}{l}\text { Per capita income (3 years average) } \\
\text { Cropping intensity (CI) }\end{array}$ & 14 & 15 \\
\hline 8 & $\begin{array}{l}\% \text { of irrigated area to total cropped area (3 years } \\
\text { average) }\end{array}$ & 14 \\
\hline 10 & $\begin{array}{l}\text { Total area under crops such as mango, grapes, } \\
\text { pomegranate, citrus, papaya, cashew nut and others }\end{array}$ & 14 \\
\hline
\end{tabular}

\section{Approach to Vulnerability Assessment}

Vulnerability is often reflected in the state of the economic system as well as the socio-economic features of the population living in that system. It is attempted to build a picture of the socio-economic context of vulnerability by focusing on indicators that measure both the state of development of the people as well as its capacity to progress further. In addition, vulnerability index for all districts of Karnataka is constructed and based on the index; districts are ranked in terms of their performance (Table 3). The index attempts to capture the comprehensive scale of vulnerability by considering some of the key indicators (that serve as proxies) for the assessment (Table 4).

There is consensus among researchers to address vulnerability issues at the regional level (Hiremath and Shiyani, 2013). Adopting the definition of vulnerability given by IPCC, Rama Rao et al., 2016 have assessed vulnerability for 572 rural districts of India. Thirty eight indicators reflecting sensitivity, adaptive capacity and exposure were chosen to construct the composite vulnerability index. The analysis showed that districts with higher levels of vulnerability are located in the western and peninsular India. In this paper, districts were taken as units for developing vulnerability indices and important indicators were selected for vulnerability assessment. These indicators have been selected based on consultation with experts, and studies reported (Hiremath and Shiyani, 2013, Khan and Salman, 2012, Swain and Swain, 2011, ICRISAT, 2009). After the selection of indicators, data pertinent to the selected indicators were compiled (Table 4). Further, a Principle Component Analysis (PCA) was conducted to identify variability among the selected variables and vulnerability indices were developed.

Table 4. Indicators used in this study and rationale

Sl. Indicators Rationality

\section{Agriculture}

$1 \quad$ Net sown area (3 years' average)

Represents the total area sown with crops

2 Cropping intensity

Higher cropping intensity means that a higher portion of the net area

cropping intensity, greater is the efficiency of land use
is being cropped more than once during one agricultural year. Higher Higher the area under commercial crops, lesser vulnerability (market

3 Percentage of area under linkage) commercial crops to TCA High value cash crops represent one potential avenue of crop intensification

\begin{tabular}{cll}
\hline 4 & $\begin{array}{l}\text { Percentage of irrigated area to TCA } \\
\text { (3 years' average) }\end{array}$ & $\begin{array}{l}\text { Irrigation has the potential to provide higher yields than rainfed } \\
\text { agriculture and reduce the insecurity of crop production }\end{array}$ \\
\hline 5 & No. of tractors/1000 ha area sown & $\begin{array}{l}\text { More tractors for agricultural activities (mechanization), increase the } \\
\text { efficiency in production }\end{array}$ \\
\hline 6 & $\begin{array}{l}\text { \% fallow land as proportion of total } \\
\text { graphical area (3 years' average) }\end{array}$ & Higher fallow land means more non utilization of resources \\
\hline 7 & $\begin{array}{l}\text { No. of agricultural cooperative } \\
\text { credit societies/lakh population }\end{array}$ & $\begin{array}{l}\text { It is a grass roots financial institution and provides credit to farmers in } \\
\text { times of need, securing crop production }\end{array}$ \\
\hline
\end{tabular}

Socio-economic and livelihoods 


\begin{tabular}{llll}
\hline 1 & Population density & $\begin{array}{l}\text { Higher the density, more dependency on finite resources and lower the } \\
\text { availability of resources }\end{array}$ \\
\hline 2 & $\begin{array}{l}\text { Percentage of SC and ST } \\
\text { population }\end{array}$ & $\begin{array}{l}\text { They are among the poor and vulnerable (both socially and } \\
\text { economically) }\end{array}$ \\
\hline 3 & Literacy rate & $\begin{array}{l}\text { Higher the literacy rate, higher the adaptation capacity, higher the } \\
\text { appropriation of opportunities and higher the awareness to face any } \\
\text { shock and stress }\end{array}$ \\
\hline 4 & $\begin{array}{l}\text { Percentage of marginal land holders } \\
\text { (<1 ha) }\end{array}$ & $\begin{array}{l}\text { Higher the proportion of marginal farmers, lesser the production and } \\
\text { income and thus higher the vulnerability }\end{array}$ \\
\hline 5 & Percentage of non-workers & $\begin{array}{l}\text { More unemployment, more dependency, lower will be the earning } \\
\text { capacity and income as compared to expenditure and thus higher } \\
\text { vulnerability }\end{array}$ \\
\hline 6 & Livestock units per lakh population & $\begin{array}{l}\text { Animal husbandry is an important source of livelihood for rural } \\
\text { communities. Livestock provides alternate sources of income to } \\
\text { farmers, thus supporting their sustainable livelihood }\end{array}$ \\
\hline 7 & $\begin{array}{l}\text { Per capita income } \\
\text { average) }\end{array}$ & $\begin{array}{l}\text { Higher per capita, higher standard of living } \\
\text { Cropping intensity }\end{array}$ & $\begin{array}{l}\text { Higher cropping intensity means that a higher portion of the net area } \\
\text { is being cropped more than once during one agricultural year. Higher } \\
\text { cropping intensity, greater is the efficiency of land use }\end{array}$ \\
\hline 9 & $\begin{array}{l}\text { Percentage irrigated area to total } \\
\text { cropped area (3 years' average) }\end{array}$ & $\begin{array}{l}\text { Irrigation protects crop production in the light of climate variations } \\
\text { and extremes like drought }\end{array}$ \\
\hline 10 & $\begin{array}{l}\text { Total area under fruit crops } \\
\text { Alternative source of farm based income }\end{array}$ \\
\hline
\end{tabular}

Figure 3 presents the details of the method adopted for assessment of vulnerability across the districts of Karnataka.

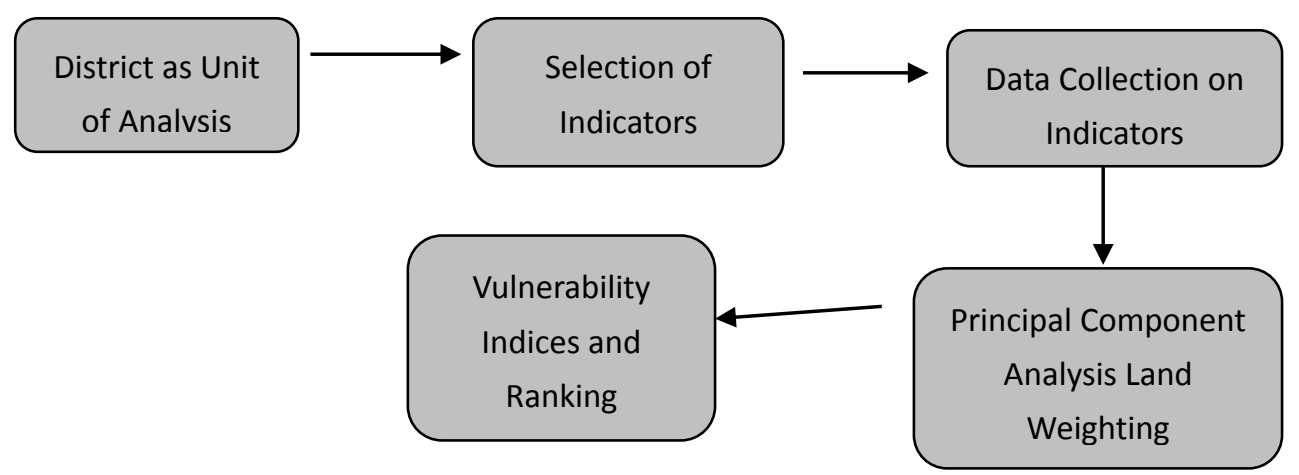

Figure 3. Framework of assessment of vulnerability

\subsection{Principal Component Analysis (PCA)}

A PCA was conducted to identify the variability among selected variables (indicators) for this study. PCA is a data reduction methodology that identifies smaller number of components that explains most of the variance observed in the larger data set. The goal is to arrive at a minimum number of components that will adequately account for the covariation among the larger number of analysis variables. PCA is a tool that converts a number of potentially correlated variables into a set of uncorrelated variables that capture the variability in the underlying data. It is a statistical method that thus transforms a given data set to a smaller number of uncorrelated variables called principal components (PCs). The first PC accounts for a large share of variability in the data, and each succeeding component accounts for as much of the remaining variability as possible. PCA approach provides several potential advantages in the aggregation of spatially explicit, potentially incommensurable variables. When the original variables are correlated then the higher order PCs will capture more of the total variability in the data than any individual original variable. Excluding the lower order PCs reduces the dimensionality (number of variables) of the data while 
minimising the loss of information (Smith, 2002). PCA thus helps reduce from a large number of individual indicators to a small number of composite, unit-less indices (PCs) while reducing the trade-off between richness of information and communicability (see Table 5 and 6).

PCA helped with generation of the weights, based on the assumption that there are common factors that explain the variance in the vulnerability. Varimax rotation was performed on the results of the PCA to maximise the variance accounted by the first component. Only components with Eigen values $>1$ were included in the analysis.

Table 5. Total variance explained by principal components for agricultural vulnerability

\begin{tabular}{lllllll}
\hline $\begin{array}{l}\text { Compone } \\
\text { nt }\end{array}$ & \multicolumn{2}{c}{ Initial Eigen values } & \multicolumn{2}{c}{ Rotation sums of squared loadings } \\
\hline & Total & $\begin{array}{c}\% \\
\text { variance }\end{array}$ & $\begin{array}{l}\text { Cumulative } \\
\%\end{array}$ & Total & $\begin{array}{c}\% \\
\text { variance }\end{array}$ & $\begin{array}{l}\text { Cumulative } \\
\%\end{array}$ \\
\hline 1 & 2.192 & 31.309 & 31.309 & 1.815 & 25.924 & 25.924 \\
\hline 2 & 1.566 & 22.369 & 53.678 & 1.659 & 23.699 & 49.623 \\
\hline 3 & 1.292 & 18.454 & 72.133 & 1.576 & 22.510 & 72.133 \\
\hline 4 & 0.836 & 11.946 & 84.079 & & & \\
\hline 5 & 0.543 & 7.754 & 91.832 & & & \\
\hline 6 & 0.385 & 5.504 & 97.337 & & & \\
\hline 7 & 0.186 & 2.663 & 100.000 & & & \\
\hline
\end{tabular}

Based on Statistical Packages for Social Sciences output, the findings of the study for the agriculture and socio-economic based classification on vulnerability indicators revealed three components, each with Eigen values greater than 1 (Tables 5 and 6). These two PCA results explain $72 \%$ and $67 \%$ of the total variation in the two data sets.

Table 6. Total variance explained by principal components for socio-economic and livelihood vulnerability

\begin{tabular}{lllllll}
\hline \multirow{2}{*}{ Component } & \multicolumn{3}{l}{ Initial Eigen values } & \multicolumn{3}{c}{ Rotation sums of squared loadings } \\
\cline { 2 - 7 } & Total & $\begin{array}{l}\% \\
\text { variance }\end{array}$ & Cumulative \% & Total & $\begin{array}{c}\% \\
\text { variance }\end{array}$ & Cumulative $\%$ \\
\hline 1 & 3.531 & 35.307 & 35.307 & 3.086 & 30.856 & 30.856 \\
\hline 2 & 1.825 & 18.247 & 53.553 & 2.032 & 20.315 & 51.171 \\
\hline 3 & 1.328 & 13.284 & 66.837 & 1.567 & 15.666 & 66.837 \\
\hline 4 & 0.995 & 9.953 & 76.790 & & & \\
\hline 5 & 0.795 & 7.949 & 84.739 & & & \\
\hline 6 & 0.651 & 6.507 & 91.246 & & & \\
\hline 7 & 0.355 & 3.545 & 94.792 & & & \\
\hline 8 & 0.234 & 2.341 & 97.132 & & & \\
\hline 9 & 0.163 & 1.629 & 98.762 & & & \\
\hline 10 & 0.124 & 1.238 & 100.000 & & & \\
\hline
\end{tabular}

There is subjectivity in assigning weights to indicators in vulnerability assessments. In order to overcome this problem, we employed the PCA technique through which we reduced the number of variables and also obtained weights (Eigen values) for the PCs. In the present study, weights are not therefore arbitrarily assigned but determined endogenously from the data matrix. The weights of the PCs are the corresponding Eigen values (Figures 4 and 5). Bangalore (U) is not included in the construction of vulnerability index. This is due to the fact that Bangalore (U) is the capital city of Karnataka and since last one decade, agricultural activities have been reduced rapidly. It was observed that in some districts of Western Ghats region, agricultural indicators are performing very poor and also affecting index values of other districts while constructing vulnerability index. Therefore, Bangalore (U), Uttara 
Kannada, Dakshina Kannada and Udupi districts were considered as outlier districts and excluded from agricultural vulnerability index analysis.

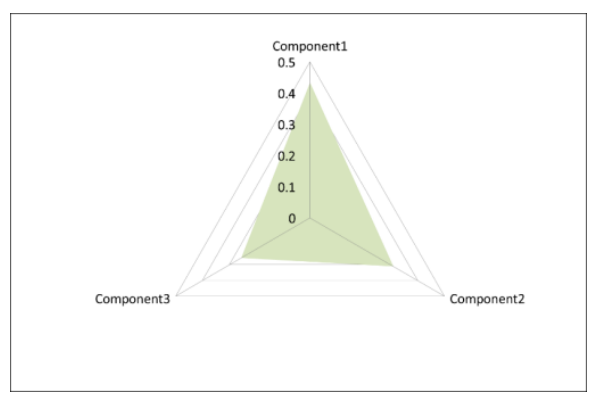

Figure 4. Weights for agricultural component indicators generated by PCA

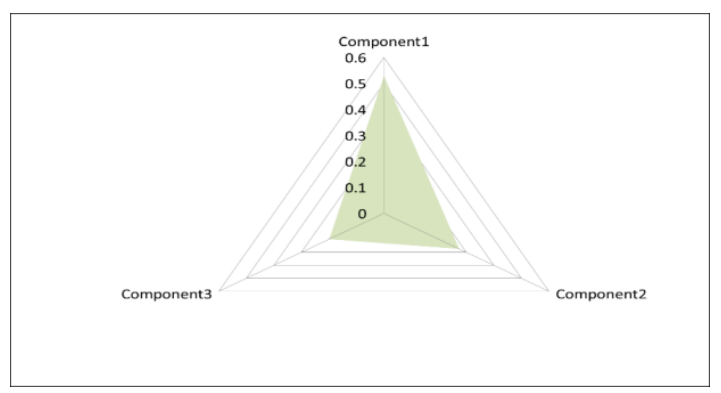

Figure 5. Weights for socio-economic component indicators generated by PCA

\subsection{Agricultural Vulnerability Index for the Districts of Karnataka}

In the present study, seven indicators were considered for the development of agricultural vulnerability index (Table 4). Based on PCA, agricultural vulnerability index values for all the districts of Karnataka are analyzed. Rank 1 indicates maximum vulnerability and the vulnerability decreases with increasing rank. Figures 6 and 7 depict the agricultural and livelihood vulnerability of the districts of Karnataka. Areas in red are the most vulnerable districts and those in green are the least vulnerable districts of Karnataka. Table 9 gives the details of significance of variables that explain variation in each component. The rotated factor analysis generated three components which account for approximately $72 \%$ of the total cumulative variance in agricultural vulnerability (Table 7).

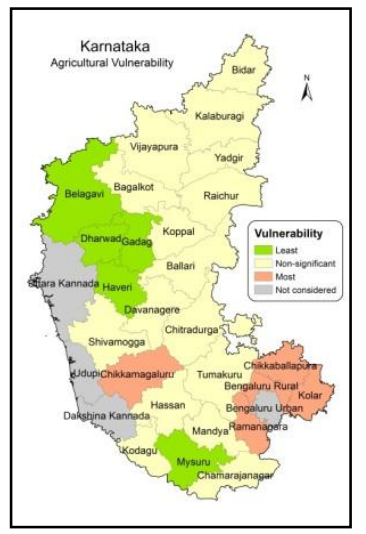

Figure 6. Agricultural vulnerability index

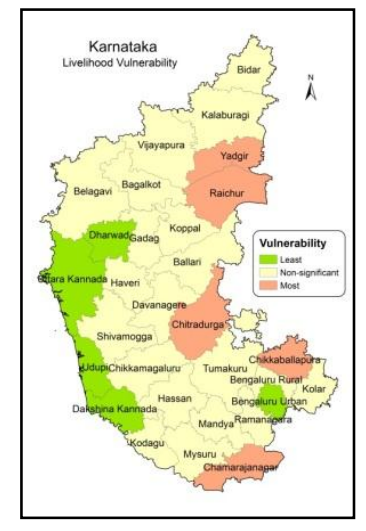

Figure 7. Livelihood vulnerability index

In component 1 , about $26 \%$ of variation is explained by 3 variables, namely, $\%$ of gross area irrigated, cropping intensity and $\%$ of commercial crops to TCA 
In component 2 , about $24 \%$ of variation is explained by 2 variables, namely, $\%$ of NSA to total geographical area and number of tractors per thousand hectares area sown

$>$ In component 3 , about $22 \%$ of variation is explained by 2 variables, i.e., $\%$ of fallow land to total geographical area, and agricultural cooperative societies per lakh population

Table 7. Rotated component matrix for agricultural indicators

\begin{tabular}{llll}
\hline \multirow{2}{*}{ Agricultural Indicator } & \multicolumn{3}{l}{ Component } \\
\cline { 2 - 4 } & $\mathbf{1}$ & $\mathbf{2}$ & $\mathbf{3}$ \\
\hline \% of net sown area to total geographical area (TGA) & 0.190 & 0.836 & 0.085 \\
\hline Cropping intensity & 0.754 & 0.269 & 0.089 \\
\hline \% of gross Irrigated area to total cropped area (TCA & 0.685 & 0.369 & 0.220 \\
\hline \% of fallow land to TGA & 0.286 & 0.237 & 0.779 \\
\hline \% of area under commercial crops to TCA & 0.793 & 0.284 & 0.415 \\
\hline No. of tractors/1000 ha area sown & 0.007 & 0.772 & 0.103 \\
\hline Agricultural cooperative societies/lakh population & 0.172 & 0.140 & 0.850 \\
\hline
\end{tabular}

\subsection{Livelihoods Vulnerability Index for the Districts of Karnataka}

For development of the socio-economic vulnerability index, ten important indicators described in Table 8 were considered. As agriculture is a dominant livelihood activity, a few agricultural indicators have also been included in the development of this index.

Rank 1 indicates maximum vulnerable district and vulnerability decreases with increasing rank. PCA shows that Yadgir, Chitradurga, Raichur, Chamarajanagara and Chikkaballapura are the top five socio-economically vulnerable districts. Bengaluru Urban, Dakshina Kannada, Udupi, Dharwad and Uttara Kannada are the least socio-economically vulnerable districts of Karnataka. Figure 7 depicts the socio-economically vulnerable districts of Karnataka, with red and green coloured areas representing most and least vulnerable districts, respectively. The rotated factor analysis generated 3 components which account for approximately $67 \%$ of the total cumulative variance in socio-economic and livelihood vulnerability (Table 8).

- Factor 1 that accounts for the largest variance (about 31\%) includes population density, percentage of literacy rate, livestock unit/lakh population and per capita income.

- In component 2, 20\% variation is explained by 3 variables, namely, percentage of SC and ST population, percentage of marginal land holders and total area under fruit crops.

- In factor 3,16\% of variation is explained by 3 variables, namely, percentage of non-workers, cropping intensity and percentage of irrigated area.

Table 8. Rotated component matrix for socio economic indicators

\begin{tabular}{llll}
\hline \multirow{2}{*}{ Socio Economic Indicator } & \multicolumn{3}{l}{ Component } \\
\cline { 2 - 4 } & $\mathbf{1}$ & $\mathbf{2}$ & $\mathbf{3}$ \\
\hline Density of population & 0.825 & 0.040 & 0.076 \\
\hline \% SC \& ST population & 0.467 & 0.529 & 0.404 \\
\hline Total literacy rate (\%) & 0.628 & 0.558 & 0.001 \\
\hline \% of marginal land holders & 0.172 & 0.802 & 0.229 \\
\hline \% of non-workers & 0.329 & 0.224 & 0.739 \\
\hline Livestock units per lakh Population & 0.850 & 0.105 & 0.107 \\
\hline Per capita income & 0.875 & 0.202 & 0.112 \\
\hline Cropping intensity & 0.142 & 0.302 & 0.668 \\
\hline \% gross Irrigated area to total cropped area & 0.382 & 0.272 & 0.563 \\
\hline Total area under fruit crops & 0.034 & 0.728 & 0.110 \\
\hline
\end{tabular}




\section{Discussion and Drivers of Vulnerability}

Karnataka state in India has the second largest area under rainfed agriculture after Rajasthan in the country and the agriculture sector is vulnerable to climate variability and change. Several studies have shown that climate change occurs in Karnataka. Long-period rainfall analysis indicated that in general, south-eastern region of the state is becoming slightly wetter, while parts of Malnad region becoming drier. Shivamogga district experienced great reduction in annual rainfall of about $460 \mathrm{~mm}$. Neighbouring Udupi district shown increase in rainfall by about 250 $\mathrm{mm}$. Majority of the districts in northern and north-eastern region, show slight reduction in annual rainfall. Region-wise analysis has shown that meteorological droughts of "Moderate" category are increasing in North Interior Karnataka, while "Severe" category droughts are increasing in South Interior Karnataka. No trends were seen for the Coastal Karnataka regions. Dry spells leading to drought in the flowering and grain-filling stages will affect crop yields adversely.

Two vulnerability indices were developed at the district level of Karnataka state, i.e., agricultural vulnerability index and socio-economic vulnerability index, for all the 30 districts of Karnataka. In order to derive these indices, a PCA was run on a data set of ten carefully selected indicator variables to represent socio-economic vulnerability and seven indicators for agricultural vulnerability across the districts of Karnataka. The PCA generated three components for each index that broadly represented the underlying themes of agriculture and socio-economic vulnerability present in the larger data set. The findings suggest:

$>$ Agricultural vulnerability

- Kolar, Ramanagara, Chikkaballapura, Bengaluru Rural and Chikkamagaluru are most agriculturally vulnerable districts of Karnataka

- Belagavi, Haveri, Gadag, Mysuru and Dharwad are least agriculturally vulnerable districts

$>$ Socio-economic and livelihood vulnerability

- Yadgir, Chitradurga, Raichur, Chamarajanagara and Chikkaballapura districts are most vulnerable districts of Karnataka

- Bengaluru Urban, Dakshina Kannada, Udupi, Dharwad and Uttara Kannada are least vulnerable districts

The result of agricultural vulnerability index suggests indicators like cropping intensity, gross area irrigated and commercial crop area are the major drivers in determining the vulnerability of districts. The livelihood vulnerability index analysis suggests Yadgir, Chitradurga, Raichur, Chamarajanagara and Chikkaballapura are the most vulnerable districts in Karnataka. The livelihood index depicts indicators like per capita income, population density, percentage of literacy rate and livestock units / lakh population, which are the major drivers and contribute to the overall livelihood vulnerability of districts.

\section{Acknowledgement}

This paper is based on two larger studies: a) One, supported by the Global Green Growth Institute and carried out by the Center for Ecological Economics and Natural Resources of Institute for Social and Economic Change, Bengaluru, India; and b) Two, on-going research on climate change and vulnerability in South India, by the ICRISAT Development Centre of the International Crops Research Institute for the Semi-Arid Tropics, Patancheru, Telangana, India.

\section{References}

Allen, K. (2003). Vulnerability reduction and the community-based approach. In Pelling (Ed.), Natural Disasters and Development in a Globalizing World (pp. 170-184). Routledge, London, UK.

Devappa, V. M., \& Khageshan, P. (2011). Analysis of rainfall in assessing drought using RS and GIS- A case study of Gulbarga district in Karnataka. Hydrology Journal, 34(1\&2), 1-12.

Environmental Management, Policy Research Institute (EMPRI), \& The Energy and Resources Institute (TERI). (2012). Karnataka State Action Plan on Climate Change, 1st Assessment.

FAO. (2016). The State of Food and Agriculture 2016 (SOFA). Food and Agriculture Organization of the United Nations (FAO), pp. 194.

Fussel, H. M. (2007). Vulnerability: A generally applicable conceptual framework for climate change research. Global Environmental Change, 17, 155-167. https://doi.org/10.1016/j.gloenvcha.2006.05.002 
Government of Karnataka. (2005). Human Development Report, Karnataka. Government of Karnataka, Bangalore, India.

Hiremath, D., \& Shiyani, R. L. (2013). Analysis of vulnerability indices in various agro-climatic zones of Gujarat. Indian Journal of Agricultural Economies, 68(1), 122.

ICRISAT. (2009). Quantitative assessment of vulnerability to climate change. Retrieved August, 2013, from http://www.icrisat.org/what-we-do/impi/training-cc/october-2-3 2009/vulnerability-analysis-manual.pdf

IISC. (2013). Environmental Benefits and Vulnerability Reduction through Mahatma Gandhi National Rural Employment Guarantee Scheme. Synthesis Report 2013. Indian Institute of Science, Bangalore, India.

IMD. (2015). 110 Years (1901-2010) Monthly Rainfall Data Series for Districts, States, Met-Subdivisions and all India. Climate Application Group, Office of the Additional Director General of Meteorology (Research), Pune, Maharashtra, India.

IPCC. (1996). Climate Change 1995 Second Assessment Report of the Intergovernmental Panel on Climate Change. Geneva, Switzerland.

IPCC. (2001). Climate Change 2001: The Scientific Basis. Contribution of Working Group I to the Third Assessment Report of the Intergovernmental Panel on Climate Change. UK, Cambridge: Cambridge University Press.

IPCC. (2007). IPCC Fourth Assessment Report: Climate Change 2007 (AR4). UK, Cambridge: Cambridge University Press.

Karade, J. (2008). Development of Scheduled Castes and Scheduled Tribes in India. UK: Cambridge School of Publishing.

Khan, F. A., \& Salman, A. (2012). A simple human vulnerability index to climate change hazards for Pakistan. International Journal of Disaster Risk Science, 3(3), 163-176. https://doi.org/10.1007/s13753-012-0017-z

Neil, A. W., Brooks, N., Bentham, G., Agnew, M., \& Eriksen, S. (2004). New Indicators of Vulnerability and Adaptive Capacity. Technical Report 7, Tyndall Centre for Climate Change Research, Norwich, UK.

Nicholls, R. J., Hoozemans, F. M. J., \& Marchand, M. (1999). Increasing flood risk and wetland losses due to global sea-level rise: regional and global analyses. Global Environmental Change, 9, S69-S87. https://doi.org/10.1016/S0959-3780(99)00019-9

Panduranga, B. T., Babu Ravindra, H. L., Guruprasad, N. A., Janardhanagowda, \& Rajegowda, M. B. (2006) Climate change and agriculture - A case study of Tumkur district in Karnataka State. Journal of Agrometeorology, 8(2), 274-277.

Porter, J. R., Xie, L., Challinor, A. J., Cochrane, K., Howden, S. M., Iqbal, M. M., ... Travasso, M. I. (2014). Food security and food production systems. In Field, C. B., Barros, V. R., Dokken, D. J., Mach, K. J., Mastrandrea, M. D., Bilir, T. E., ... White, L. L. (Eds.), Climate Change 2014: Impacts, Adaptation, and Vulnerability. Part A: Global and Sectoral Aspects. Contribution of Working Group II to the Fifth Assessment Report of the Intergovernmental Panel on Climate Change (pp. 485-533). Cambridge, United Kingdom: Cambridge University Press.

Rajegowda, M. B. (1992, October 8-9). Effect of variation in forest area on rainfall and temperature. National Seminar on Radiation, Environment and Man (REM). Mysore University, Mysore.

Rajegowda, M. B., Muralidhara, K. S., Murali, N. M., \& Kumar, A. T. N. (2000). Rainfall shift and its influence on crop sowing period. Journal of Agrometeorology, 2(1), 2002.

Raju, K. V., Deshpande, R. S., \& Bedamatta, S. (2016). Vulnerability to Climate Change: A Sub-regional Analysis of Socio-economic and Agriculture Sectors in Karnataka, India. Journal of Development Policy and Practice, 2(1), 24-55. https://doi.org/10.1177/2455133316676402

Rao, K. A. V. R., Wani, S. P., \& Srinivas, K. (2016). Climate Variability and Agriculture. In K. V. Raju, \& S. P Wani (Eds.), Harnessing Dividends from Drylands: Innovative Scaling up with Soil Nutrients (pp. 136-175). CAB International.

Rao, K. A. V. R., Wani, S. P., Singh, K. K., Ahmed, M. I., Srinivas, K., Snehal, D. B., \& Ramadevi, O. (2013). Increased arid and semi-arid areas in India with associated shifts during 1971-2004. Journal of Agrometeorology, 15(1), 11-18. https://doi.org/10.1079/9781780648156.0136 
Rao, R. C. A., Raju, B. M. K., Rao, S. A. V. M., Rao, K. V., Rao, V. U. M., Ramachandran, K., ... Rao, S .C. H. (2016, May 25). A district level assessment of vulnerability of Indian agriculture to climate change. Current Science, 110(10), 1939-46. https://doi.org/10.18520/cs/v110/i10/1939-1946

Sehgal, V. K., Singh, M. R., Chaudhary, A., Jain, N., \& Pathak, H. (2013). Vulnerability of Agriculture to Climate Change: District Level Assessment in the Indo-Gangetic Plains, p. 74. Indian Agricultural Research Institute, New Delhi.

Senbeta, A. F. (2009). Climate Change Impact on Livelihood, Vulnerability and Coping Mechanisms: A Case Study of West Arid Zone, Ethiopia. MSc thesis submitted to Lund University Masters Program in Environmental Studies and Sustainability Science (LUMES), Lund, Sweden.

Shashidhara, K. K., \& Reddy, B. S. (2012, January), Farmers' perceptions and adaptation about changing climate and its variability in UKP area of Karnataka. Indian Research Journal of Extension Education, I, 196-201.

Singh, R. B., Singh, A., \& Kumar, A. (2014). Climate change variability in coastal Karnataka, India. Climate Change and Biodiversity. In Singh, M., Singh, R. B., \& Hassan, M. I. (Eds.), Proceedings of IGU Rohtak Conference (Vol. 1). Advances in Geographical and Environmental Sciences.

Smith, L. I. (2002). A Tutorial on Principal Component Analysis, Vol. 2012. Elementary Linear Algebra 5e, Howard Anton, willey, $\mathrm{J}$ and sons Inc.

Stern, N., Peters, S., Bakhshi, V., Bowen, A., Cameron, C., Catovsky, S.,.. Dietz, S. (2006). Stern Review: The economics of climate change. OUP.

Swain, M., \& Swain, M. (2011). Vulnerability to agricultural drought in Western Orissa: A case study of representative blocks. Agricultural Economics Research Review, 24, 47-56.

Venkatesh, H., Kumar, K. K., Aski, S. G., \& Kulkarni, S. N. (2008). Impact of climate change on agriculture over northern Karnataka. In Rao, P. G. S. L. H. V., Rao, G. G. S. N., Rao, V. U. M., \& Ramakrishna, Y. S. (Eds.), Climate Change and Agriculture over India (pp. 113-128).

Watson, R. T., Zinyoera, M. C., \& Moss, R. H. (1996). The Regional Impact of Climate Change: An Assessment of Vulnerability. A Special Report of IPCC Working Group II. UK, Cambridge: Cambridge University Press.

\section{Notes}

Note 1. Scripps CO2 Program http://scrippsco2.ucsd.edu accessed on 23 November 2016

Note 2. Abbreviations used are Bagalkote (BGLK), Ballari (BLLR), Belagavi (BLGV), Bengaluru Rural (BNGR), Bengaluru Urban (BNGU), Bidar (BIDR), Chamarajanagara (CHMR), Chikkaballapura (CKBP), Chikkamagaluru (CKMG), Chitradurga (CHTD), Dakshina Kannada (DKKN), Davanagere (DVNG), Dharwad (DHWD), Gadag (GDAG), Hassan (HSSN), Haveri (HVRI), Kalaburagi (KLBR), Kodagu (KDGU), Kolar (KOLR), Koppal (KPPL), Mandya (MNDY), Mysuru (MYSU), Raichur (RCHU), Ramanagara (RMNG), Shivamogga (SVMG), Tumakuru (TMKU), Udupi (UDPI), Uttara Kannada (UTKN), Vijayapura (VJYP) and Yadgir (YDGR).

Note 3. http://raitamitra.kar.nic.in/stat/kacz.htm accessed 21 September 2016 